This article surveys and analyzes the contemporary reception of Plato's rhetorical theory in contemporary rhetoric and composition studies by examining the response from three current perspectives: (1) presenting Plato as completely against rhetoric; (2) leaving Plato out of rhetoric altogether; and (3) interpreting Plato's work as raising issues central to classical and contemporary rhetoric. The discussion of the first two responses to Plato's relationship to rhetoric reveals a reductive, or formulaic, presentation of classical rhetoric. The discussion of the third perspective shows that it is the most accurate interpretation. Plato's rhetoric is related to the traditional five canons that were prominent in Greek rhetoric and explicitly systematized in Roman rhetoric, beginning with the Rhetorica Ad Herennium. If Plato's extensive contribution to the last two of the classical canons of rhetoric, memory and delivery, were more commonly included in the historicizing of rhetoric, then the five canons would work in the fullness of their interaction, rather than as the three-part system (invention, arrangement, and style) that dominates much current interpretation of classical rhetoric. Examples of reintegration of Plato into classical rhetoric (the third perspective) leads to a conclusion that Plato's rhetoric is central to contemporary interpretations of classical rhetoric.

\title{
The Platonic Paradox
}

\author{
Plato's Rhetoric in Contemporary \\ Rhetoric and Composition Studies
}

\author{
KATHLEEN E. WELCH \\ University of Oklahoma
}

Like all masters of literature, Plato has of course varied excellences; but perhaps none of them has won for him a larger number of friendly readers than this impress of visible reality. For him, truly (as he supposed the highest sort of knowledge must of necessity be) all knowledge was like knowing a person. The Dialogue itself, being, as it is, the special creation of his literary art, becomes in his hands, and by his masterly conduct of it, like a single living person. (Pater, 1910)

Author's Note: This article was written with a grant from the College of Arts and Sciences of the University of Oklahoma. The research was conducted partly with the aid of a University of Oklahoma Research Council grant.

WRITTEN COMMUNICATION, Vol. 5 No. 1, January 1988 3-21

() 1988 Sage Publications, Inc. 
The reception of Plato's rhetoric in the rhetoric and composition renaissance of the last 20 years offers us insight into our own philosophies of language as we develop new theories of writing and rhetoric. In much of the work on rhetoric in the last generationespecially in the historicizing of rhetorical theory-Plato has been made to disappear or, more seriously, has been made to stand against rhetoric. Both interpretations have serious consequences for the theoretical bases of current work in rhetoric and composition; they determine to a large extent how rhetoric exists. Such receptions show us the results of theory unconsciousness or the denial that all language study depends on theory. Partly because Plato's rhetoric is so often theoretical, so concerned with systems of underlying relationships and principles that inform surface language issues, many contemporary scholars in rhetoric and composition have ignored Plato. Doing so has been made easier because tacit permission has been granted by the researchers who dispense with Plato's rhetoric by writing as if it did not exist or as if he disowned all of rhetoric. Further tacit permission has been granted by those who treat theory and practice as completely separate activities rather than as interrelated parts. This article examines three kinds of contemporary reception of Platonic rhetoric: (1) the position that Plato is antirhetoric; (2) the position that Plato has nothing to do with rhetoric; and (3) the position that dialectically engages Plato's rhetoric. These different receptions allow us to construct historical rhetoric in different ways, and to consider how contemporary composition and rhetoric is in large part created by them.

The first kind of reception, the removal of Plato, focuses on the form that many contemporary discussions of classical rhetoric assume. One important example is John H. Mackin's Classical Rhetoric for Modern Discourse. The subtitle of this 1969 book, An Art of Invention, Arrangement and Style for Readers, Speakers and Writers, indicates its deletion of two of the five canons. The structure consists of ordering the material of discourse into the categories of the first three of the five canons of rhetoric: invention, arrangement, and style.

While the five departments of rhetoric were not canonized until Roman rhetoric, they are apparent in Greek rhetoric. In fact, Aldo Scaglione states in The Classical Theory of Composition that the five canons can be found in Aristotle (1932, p. 14). Ray Nadeau, in "Delivery in Ancient Times: Homer to Quintilian," demonstrates 
that the fourth canon held great importance for Isocrates, Aristotle, and other Greek rhetoricians (1969; pp. 53-54). He cites the many quotations of Demosthenes claiming "rhetoric is delivery" (1969, p. 54). The centrality of the fifth canon, memory, in Greek rhetoric is argued by Frances A. Yates in The Art of Memory (1966), in which she connects the Roman treatise Rhetorica Ad Herennium to earlier Greek work:

An immense weight of history presses on the memory section of $A d$ Herennium. It is drawing on Greek sources of memory teaching, probably in Greek treatises on rhetoric, all of which are lost. It is the only Latin treatise on the subject to be preserved, for Cicero's and Quintilian's remarks are not full treatises and assume that the reader is already familiar with the artificial memory and its terminology. It is thus really the main source, and indeed the only complete source, for the classical art of memory both in the Greek and in the Latin world. (p. 5)

Scaglione, Nadeau, and Yates show the existence and the importance of the five canons during Plato's time. The Greek names of the five canons (erga) were available, as Scaglione mentions (1972, p. 14): heúresis, táxis, léxis, mnéme, and hypócrisis.

Constructions such as Mackin's could not exist if Plato's rhetoric were included. In fact, Mackin's construction does not appear to be radical because we are all so familiar with it; the deletion has become commonplace in rhetoric and composition. Familiarity disguises its revolutionary consequences and conditions us to experience the removal as "normal." For example, the first three canons organize the vast majority of writing textbooks. An analysis of the results of eliminating two of the classical canons can reveal some of the unconscious uses of language theory. Looking at the deletion of two-fifths of the canons can show us something about Plato's conceptualization of rhetoric. If memory and delivery are ignored, we have effectively ignored much of the contribution Plato made to rhetoric.

All composing is recursive and dependent on the organic interrelationships of the recursive movements. In other words, composing is not linear and divisible into discrete parts. It is noteworthy that the Greek word for composition is synthesis. All aspects of composing merge in various ways with one another. Invention, for example, is a 
primary generating issue in all five canons. While we can isolate it-as much excellent research in invention in the last 15 years amply shows us-we need to maintain its sense of recursiveness and recognize its presence in every aspect of composing, regardless of whether we order it according to the classical canons or according to some other structure. Form partakes of the same recursiveness, as do style, memory, and delivery. The five canons work together to maintain this synergistic, mutually dependent relationship. Part of this inclusiveness derives from the contact with culture and public life that characterizes all 700 years of classical rhetoric in Greece and Rome. The power of classical rhetoric always resided in its symbiotic relationship with Greek and Roman culture and politics. When the canons are reduced to three composing issues-invention, arrangement, and style-not only is the definitive energy of the fluctuation among them deeply affected, but the relationship to culture assured by delivery disappears and the idea of category-for-category's sake is able to acquire more importance. The deletion of memory and delivery from any canonical system undercuts the intentions and rhetorical fullness of the five-part structure. In addition, their deletion by us ignores the orally based rhetoric that was the foundation for writing.

The motives for memory and delivery's consistent removal usually center on the association of memory and delivery with the dominance of oral discourse. However, this widespread assumption that oral dominance and writing dominance are easily separable and that writing dominance did not occur until after the height of classical rhetoric is refuted by the research of Eric A. Havelock and Walter J. Ong (Havelock, 1963, 1978; Ong, 1958, 1981a, 1981b, 1982), among others. Their work shows that written discourse began assuming major rhetorical importance by the fourth century B.C. when Plato was writing his dialogues (Havelock, 1978, p. 4). Certainly by the time of the writing of the Rhetorica Ad Herennium, in which the canons were first codified explicitly in a document, writing had been thoroughly interiorized and was regarded as crucial to thinking. While orality was more important to the formation of consciousness (and, we might say, unconsciousness) in the classical period than it is in our own, writing was fully interiorized by the fourth century B.C. We cannot ignore this phenomenon in our conceptualization of classical rhetoric, nor can we neatly divide oral dominance and writing dominance in ancient Greece. Orality and literacy need to be 
considered together, because they worked together. Plato's work developed significantly because of the interaction of orality and literacy. The common division of these two forms of discourse, referred to in many asides on rhetoric, constitutes a factual error. In fact, the mutuality in their coexistence exerted powerful language and consciousness changes, as Ong shows. Many of the critics who remove memory and delivery from the canons regard them as mere rote memorization and as simple gesture. Yet a more careful review of these assumptions informs both our rehistoricizing of classical rhetoric and Plato's relationship to it.

The depth and complexity of memory in all stages of classical rhetoric, from Corax to Plato to Quintilian, are called to mind by George Steiner's striking explication of the commonplace phrase "by heart" as a way of indicating memorization. Remembering something, carrying something around with oneself, takes place at the center of one's being. Eugenio Montale makes the same point in his essay "The Second Life of Art." The experience that the decoder takes away from the experience of art-the reflecting and mulling that accompany the activity of experiencing effective art-is the real source of art's power. If one's memoria is not changed by the experience of art, if the experience is not taken away, then it has not been deeply felt. Both Steiner, in After Babel (1975), and Montale, in "The Second Life of Art" (1982), evoke the centrality of memory to all discourse and point to the phenomenon that memory is power.

Perhaps the most important connection that memory as a canon of rhetoric gives us is its explicit pointing to psychology. Research in cognitive psychology reveals the relationship between memory and creativity, as the work of John R. Anderson (1980) and John R. Hayes (1978), among others, has shown. While the canon of memory is certainly not the only approach to psychology and discourse, it remains an important one. Moreover, memory does not decrease in importance with the rise of writing dominance, but it changes emphasis, particularly in the formation of consciousness as it relates to technology (Ong, 1982, pp. 78-116). David S. Kaufer (1978) demonstrates Plato's connection of rhetoric and psychology. Kaufer states that

there is a systematic connection between rhetoric and psychology in the Dialogues, and it comes to this: Plato knew there was a way of using words to affect the soul for good or evil and, as he saw it, one of the tasks 
of psychology was to explain the moral difference between the two. (1978, p. 64)

When we reconstitute memory as a crucial aspect of Greek systems of rhetoric, one of the first things we discover is that memory is not merely a component of Plato's rhetoric. Memory is, as Yates claims in The Art of Memory, inherent in his rhetoric because rhetoric partakes of the Forms and the soul's attempt through language to have access to them. 'Memory is not a 'section' of this treatise, as one part of the art of rhetoric; memory in the Platonic sense is the groundwork of the whole" (1966, p. 37). Memory is also the existence of the past within the present. It is there that culture and rhetoric largely exist, for Plato and for us.

Similarly, the canon of delivery has important implications for rhetoric and composition. Rather than limiting delivery to the physical gesture and expression that take place during speaking, we can relate it to the idea of medium. This point is made in Patrick Mahoney's article "Marshall McLuhan in the Light of Classical Rhetoric" (1969) when he reveals that the fifth canon ultimately signifies medium. Mahoney states, "As a theoretician of rhetoric, McLuhan's main contribution lies in the fact that he has developed and broadened the fifth category of traditional rhetoric" (1969, p. 12). If delivery is regarded as medium, then the dynamics of the canon are reinvested with their original power. Medium in classical and contemporary rhetorical theory, as Ong (1981b, 1982), McLuhan (1962), and Febvre and Martin (1984) demonstrate, determines the power of rhetoric. A major reason for the similarly intense study of rhetorical theory in ancient Greece and in contemporary America derives from shifts in consciousness-the movement from orality to literacy-set in motion by radical change in the fifth canon. In classical Greece, the gradual interiorization of the phonetic alphabet from the eighth to the fourth centuries B.C. led to these changes in discourse, and in the contemporary period, the interiorization of electronic media in the last 100 years has been changing gradually our relationship with all kinds of discourse (Ong, 1982, p. 79). These changes are major factors in the enormous interest in rhetoric in the classical and contemporary periods and help to tie the two periods together. In The Presence of the Word (1981b, p. 18) Ong states, "Our entire understanding of classical culture now has to be revised-and with it our understanding of later cultures up to our own time-in 
terms of our new awareness of the role of the media in structuring the human psyche and civilization itself." So the fifth canon, particularly in its interaction with the four other canons and with a recognition of its recursiveness, offers us important and largely unexplored possibilities in contemporary rhetoric.

Removing memory and delivery from the canons can undermine contemporary work in rhetoric by diminishing its range. If we are going to rely on the structure of the five canons of classical rhetoric, we need either to use that structure or to explain its adaptation with great care, for the removal of two-fifths of the canons is not an adaptation but a wholly new structure that denies the central language issues of culture and power. Classical rhetoric as a system of discourse theory remains unique among the various critical theories available to us because it connects to history, politics, and the everyday uses of language. The central language issues of memory and delivery, which assumed importance in Greek rhetoric and were canonized in Roman rhetoric, are connectors to history, culture, and the life of the polis. If Plato's views were allowed to exist in classical rhetoric, then a structure like the truncated canons could not function. To reduce the classical canons from five to three has the same consequences as saying that Plato opposes all of rhetoric. Both these interpretations of classical rhetoric diminish its effectiveness, its range, and its current usefulness.

Plato's rhetoric bypasses helpful categorization and relies instead on the active interchange of rhetoric and dialectic between two sides actively engaged in a search. Plato attacked sophistic rhetoric. He embraced philosophical rhetoric. This oppositional view accounts for one kind of platonic paradox in rhetoric. The paradox is only apparent, however. Plato does not contradict himself. Instead, he distinguishes between sophistic rhetoric and philosophical rhetoric. He denounces the former and praises the latter kind. Plato's defense of philosophical rhetoric appears in Phaedrus explicitly and in Gorgias implicitly. In his heated attack against sophistic rhetoric in Gorgias, Plato complained about the prescriptions that the sophistic handbooks relied on. He railed against the illusory power of discourse that lacked vital connections to human thought and essential principles. He worked against the absence of thought in these handbooks and the teachers who used them. He opposed their relativistic bias because it denied his ontology of the Forms and the soul's relationship to them. Even more important, Plato could not envision a true rhetoric that 
does not deal with activity between the speaker or writer and the hearer or reader. Plato attacked sophistic rhetoric not only because it denied his conception of reality but also, crucially, because sophistic rhetoric denied activity between the message sender and receiver, and therefore allowed the soul to atrophy or, to use the imagery from Phaedrus, sophistic rhetoric pulled the soul back to the earth rather than allowing the soul to soar. Plato believed that the Sophists' rhetoric ignored the nature of dialectical inquiry. ${ }^{1}$

Plato praised philosophical rhetoric because it depends on the active use of dialectic. Passivity precludes dialectic. The activity, the interdependent exchange of ideas and emotions, the push and pull of spiraling intellectual and psychological inquiry, constitute Plato's conception of philosophical rhetoric in Phaedrus. Without dialectic, there is no real rhetoric for Plato. In the presentation of all his writing-in the letters as well as the dialogues-he indicates that rhetoric is crucial to his effective working out of dialectic. The two are intertwined for him. Consequently, the categories that deny connection and therefore activity cannot be a part of his rhetoric.

Because of Plato's unwillingness to categorize his rhetoric, it is more difficult to describe his philosophical rhetoric than Aristotle's, whose extant lecture notes invite others to formulize his rhetoric. We cannot simply excerpt a few lines-as we do so nicely with Aristotleand provide a definition of Platonic rhetoric. We have to consult the rhetorical form of Plato's work, the interaction of rhetoric and dialectic, and the psychological activity of the speaker or writer with the listener or reader. The medium of writing (that is, Plato's use of the canon of delivery) and the psychology of discourse (Plato's use of the canon of memory) combine with the canons of invention, arrangement, and style to provide a Platonic definition of rhetoric.

Plato's rhetoric is much less concerned with a large assembly of hearers or readers than he is with a series of one-to-one dialectics formed by rhetoric. Consider, for example, three of his middle group of dialogues-Phaedrus, Symposium, and Republic. In these pieces the literary characters of Phaedrus, Alcibiades, and Thrasymachus are presented as memorable individuals who interact not only with the dialogue character of Socrates but with the environments they populate. The individuals, set in the scene of a particular Athens, are active interlocutors who challenge and are challenged by Socrates. There is no Platonic dialogue without this verbal interchange of 
persuasion and belief. They are so carefully wrought that, as Walter Pater (1910) explains, the dialogues themselves become individuals with whom we interact.

The tendency to consider classical rhetoric exclusively as a public art-to envision a formal speech delivered to an assembly-has dominated contemporary studies of rhetoric. Just as important as public discourse was the individual correspondence, clash, and movement of the Platonic, "personal," rhetoric. This conceptualization of rhetoric does not depend as thoroughly on the construction of political institutions as public rhetoric. It changes as the state changes, but it does not disappear, as legislative rhetoric does with the disappearance of democracy. In the last section of Phaedrus, Socrates makes the following extension of rhetoric:

Is not rhetoric, taken generally, a universal art of enchanting the mind by arguments; which is practiced not only in courts and public assemblies, but in private houses also, having to do with all matters, great as well as small, good and bad alike, and is in all equally right, and equally to be esteemed-that is what you have heard? (Jowett, p. 305)

After an illustration of the personal kind of rhetoric that exists alongside public rhetoric, Socrates goes on to instruct young Phaedrus: "The art of disputation, then, is not confined to the courts and the assembly, but is one and the same in every use of language" (Jowett, p. 306).

Plato's rhetoric is more difficult than virtually any other rhetorician's, because it derives from the mutuality of dialectic and its connection to basic realities. Two people interact only because the rhetorical partner actively exists. This kind of movement and emphasis on individual responsibility in the rhetorical, dialectical act is not as easy to capture, to codify, even to prescribe, as rhetoric before a large audience whose interaction must by its very nature be difficult to assess. In a public forum, the audience works as a group and is largely passive. The speaker does not depend as thoroughly on the audience as the individual, dialectical version of rhetoric does. Plato makes the reader of the dialogue join Socrates and his companions in the art of private rhetoric and dialectic.

Those critics who interpret Plato as opposed to rhetoric do not consider this issue of the dialogue form in Plato and its function as 
pure rhetoric. They disregard the rhetorical nature of the form of the dialogue, emphasizing a limited aspect of Plato's conceptualization of rhetoric: They turn exclusively to his attack on sophistic rhetoric in the early Gorgias. Plato sets up his often quoted, graphic, analogical series of dangers in Gorgias's kind of rhetoric, which is presented by Plato as a trivialization of something important. Just as gymnastics and medicine can be reduced from arts to knacks by reducing them to cosmetics and cookery, so rhetoric can be reduced (Plato, 1952, p. 465). ${ }^{2}$ The crucial interpretive issue in Plato's analogical reasoning consists of two parts. Those critics who interpret Plato as thoroughly attacking rhetoric in this frequently cited passage are attending to only one-half of each analogy, namely, cosmetics and cookery. Their worthy counterparts, gymnastics and medicine, are ignored in this interpretation. In his extensive use of these ratios, Plato's Socrates points to an alternative rhetoric, one based on the pursuit of justice (diké, or balance) and the good rather than on pleasure. So even in Gorgias, a dialogue often dismissed as thoroughly against all rhetoric, Plato treats and enacts philosophical rhetoric. The form of the dialogue itself is a primary enactment of Plato's rhetoric. Cicero (1970), in Brutus, states that Plato is a very effective rhetorician in arguing against sophistic rhetoric (pp. 269-270). Critics who attend only to Plato's condemnation of sophistic rhetoric go beyond the interpretation problem of ignoring half of Plato's analogies to rhetoric. They inaccurately make a synecdoche out of the part of the analogy they do respond to; they claim, in effect, that half the analogy stands for all of Plato's conception of rhetoric, and they ignore the fact that only a rhetorician passionately committed to the possibilities of philosophical rhetoric could damn its misuse so thoroughly.

The extension of Plato's attack against sophistic rhetoric to include philosophical rhetoric is a primary characteristic of the contemporary reception of classical rhetoric. C. H. Knoblauch and Lil Brannon, in Rhetorical Traditions and the Teaching of Writing (1984), use Plato's attack on sophistic rhetoric to move forward their book-length argument that classical rhetoric largely created such modern problems in the teaching of writing as the current/traditional paradigm. Philosophical rhetoric in Plato does not exist for them. ${ }^{3}$ The mere repetition of the concept that Plato does not exist for rhetoric has provided this interpretation with much of its power.

From the antirhetoric interpretation of Plato it is a logical step to a different but related incarnation of the contemporary reception of 
classical rhetoric. This reception excludes Plato in the contemporary historicizing of rhetoric. All of rhetoric is made to begin with Aristotle. Freedman and Pringle, the editors of Reinventing the Rhetorical Tradition (1980), for example, follow this path, as does Douglas Ehninger (1968/1972) in "On Systems of Rhetoric." Critics who exclude Plato are forced to depart from the questions of philosophical rhetoric because they do not engage dialectic, its attendant psychological interactions, and the activity found in whole discourses. It is a small step from the exclusion of philosophical rhetoric to the reduction of interactive whole discourse, to fragments of discourse and the reduction of a whole, psychological being whose essential formation occurs with discourse. The avenue toward the formulizing of rhetoric therefore lies open. Rhetoric is well on its way to becoming trivial, if such a view is adopted.

The denial of philosophical rhetoric leads the way to a third kind of classical rhetoric, technical rhetoric, a dry, prescriptive, microscopic form of language use that holds the power today that sophistic rhetoric held in Plato's time. ${ }^{4}$ Almost all freshman writing books, as Mike Rose, Richard Ohmann, and others have demonstrated, emphasize this kind of static, rule-centered rhetoric. Sophistic rhetoric and technical rhetoric share the denial of the essential power of philosophical rhetoric, what some critics call "true rhetoric" (Erickson, 1979). Sophistic rhetoric enjoys the advantage over technical rhetoric of at least treating psychology and whole people. Technical rhetoric characterizes itself by a focus on fragmentary, prescribed discourse.

Leaving Plato out of our construction of rhetoric virtually assures a lapse into the prescriptions of technical rhetoric. This absence promotes the nonphilosophical thinker that Richard McKeon (1947), William M. A. Grimaldi (1972, 1980), and Richard Leo Enos (1979) have complained of and so sets the stage for a static, rule-bound rhetoric that evades the issues of thinking and discourse.

Fortunately, a third kind of reception of classical rhetoric exists. Some contemporary rhetoric and composition critics have understood the consequences of making Plato antirhetoric or of deleting him from rhetoric altogether. Such rhetoric critics as George Kennedy (1980), especially in Classical Rhetoric and Its Christian and Secular Tradition from Ancient to Modern Times, Ong (1982) in Orality and Literacy and other works, and Andrea A. Lunsford and Lisa S. Ede (1984) in "On Distinctions between Classical and Modern Rhetoric" represent an alternative contemporary reception of classical rhetoric 
by beginning with careful readings of Plato's dialogues, making connections among them, and understanding Plato's rhetoric as part of his philosophical system. These critics address Plato's rhetoric and dialectic by participating in it; Kennedy, Ong, Lunsford, and Ede are active dialecticians themselves in their studies of Plato's rhetoric.

In Classical Rhetoric in Its Christian and Secular Tradition from Ancient to Modern Times, Kennedy reads Phaedrus for us in a way that not only synthesizes but rehistoricizes subsequent views of classical rhetoric. ${ }^{5}$ Plato "lays the foundation for basic features of Aristotle's Rhetoric and he integrates rhetoric into his other philosophical ideas in a way not attempted elsewhere" (pp. 52-53). Kennedy rereads himself (1963) and shows us the psychological, erotic, and even divine attributes of Plato's rhetoric. Kennedy removes us from hyperlogical classical rhetoric as Plato himself did. Kennedy shows us how to recognize the enormous power of rhetoric and to see that it cannot be explained by cordoning off the logical aspect of the mind and separating it from the whole person.

Like Kennedy, Ong (1981b, 1982) provides a different kind of Platonic interpretation that also depends on explication of Plato's dialogues and a careful setting up of his language and context. Ong also rehistoricizes classical rhetoric by showing us that oral dominance and writing dominance are not separate spheres and that the technology of language shapes the unconscious and the conscious mind (1982, pp. 78-79). Most important for contemporary rhetoric and composition studies, Ong connects the technological struggle of Plato's time with the technological struggle we experience now with electronic media. At issue is the shaping of consciousness from which all encoding derives. In other words, Ong explains the psychology of rhetoric in Plato's context and in our own. Plato realized that writing his ideas enabled him to preserve them, in spite of his complaints against writing. With the form of the dialogue, he chose a kind of writing that resembles speaking. Psychology, particularly in its relationship to consciousness and language, is an area that most contemporary studies of classical rhetoric have ignored. This inattention has led to the removal of Plato in the historicizing of rhetoric, to a hyperlogical reduction of Aristotle's rhetoric, and to a denial of the power we derive from technology-induced shifts in consciousness. Ong states: "Technologies are artificial, but-paradox againartificiality is natural to human beings. Technology, properly interiorized, does not degrade human life but on the contrary 
enhances it" (1982, pp. 82-83). We must face the interiorization of electronic media as Plato in his rhetoric faced the interiorization of the phonetic alphabet. This treatment requires treating whole people. A second paradox of Plato's rhetoric lies in his resistance to the new technology of writing and his artistic manipulation of it.

Plato's rhetoric is very much like our own rhetoric as treated in the work of Connors, Ede, and Lunsford (1984) in Essays on Classical Rhetoric and Modern Discourse, which provides some incisive work on the epistemological similarities in classical and contemporary rhetoric. Lunsford and Ede, in their essay "On Distinctions Between Classical and Modern Rhetoric" (1984), rehistoricize rhetoric for us by analyzing an influential segment of the reception of rhetorical thought into a false dichotomy. By revealing the reductionism that has turned Aristotle, for instance, into a hyperlogical language theorist-and, by implication, Plato-they reread Aristotle by placing him within his own philosophical system:

The rational man of Aristotle's rhetoric is not a logic-chopping automaton but a language-using animal who united reason and emotion in discourse with others. Aristotle (and indeed, Plato and Isocrates as well) studied the power of the mind to gain meaning from the world and to share that meaning with others. (p. 43)

Lunsford and Ede thus reintegrate common reductions of classical rhetoric-such as interpreting classical rhetoric as logic dominantinto a wide-ranging theory of discourse. Their analysis of the contemporary reception of classical rhetoric depends on the recognition of Plato as a primary classical rhetorician.

The work of Kennedy, Ong, and Lunsford and Ede-exemplifying the third reception of classical rhetoric-successfully attempts to reconnect rhetoric with thinking, rather than with mere formulizing. These writers do not trade on Plato's image and Aristotle's authority but engage in the active search that informed all of their writing. By showing us this kind of textual interaction, Kennedy, Ong, and Lunsford and Ede remove classical rhetoric from its technological appropriators and help us restore language thinking to the center of the rhetoric and composition curriculum, usurping the static formulas and exhortations that persuade many people that it is better to dispense with classical rhetoric. 
I have presented one symptomatic reading of contemporary rhetoric and composition: that the kind of reception we give classical rhetoric-and by extension the rest of historical rhetoric-informs how we study rhetoric today. We can turn now to the issue of how we can change the condition of language study, so that philosophical rhetoric-language and thinking-gains dominance over the necessarily fragmentary technical rhetoric. One way is to consult the struggle between technical rhetoric and philosophical rhetoric that has been going on since the fourth century B.C. We need to know how the twentieth-century rhetoric resurgence fits into this history. When we better understand why rhetoric has assumed great importance again, we may be able to exploit better what Terry Eagleton (1983) calls the "forms of power and performance" (p. 206) that rhetoric gives us. ${ }^{6}$ In other words, we need to remember that we historicize ourselves as we rehistoricize Plato's work on rhetoric.

Contemporary rhetoric cannot consult these "forms of power and performance" without recognizing the struggle Plato went through with the new technology of writing. By the time Plato complains (ironically, in literary texts) that writing threatens intelligence, or the discourse status quo, there was no turning back (Ong, 1981b, 1982). In the same way, we can see that the electronic media have already changed the way consciousness is formed. We cannot choose to avoid this change. In spite of this reality, reaction to change is all around us in blanket denunciations of video, especially in the form of television and the attendant proclamations of impending universal illiteracy. Such a struggle is a struggle over rhetoric; it is analogous to the struggle between writing and speaking dominance that preoccupied Plato. As teachers and scholars of rhetoric and composition, we witness a striking example of the conflict between writing and electronic media. It comes to us in the form of a schism between traditional literary studies, which emphasize history, theme, and artistic expression, and rhetoric and composition studies, which examine any kind of writing occurring anywhere. In this schism, poststructuralist theory is on the same side as rhetoric and composition. Many aspects of rhetoric and composition and poststructuralist theory examine the assumptions of language study and radically extend the kinds of discourse to be studied. This extension of the field and, more important, the reorganization of assumptions of language study, is frequently regarded negatively by traditionalists. The struggle of composition and poststructuralism to assert themselves is 
analogous to the struggle that written discourse underwent in Plato's Athens. Shifts in consciousness do not occur easily.

When Plato appears to be ambivalent about writing and rhetoric, he was responding to sophistic rhetoric, technical rhetoric, and his sense of how these two kinds of rhetoric were exploiting very effectively the burgeoning power of the written word. He responded with his own elaborate writing, his own conception of philosophical rhetoric, and his own paideia. In other words, he reinscribed what he regarded as harmful material. So Plato was concerned not with obliterating rhetoric and its increasingly familiar discourse partner, writing, but with appropriating them to his own beliefs and directing that meaning of rhetoric to others. ${ }^{7}$

Just as Plato's intense understanding of the physical world has been denied in favor of a blatant, dualistic interpretation that places Plato in an ethereal world of invisible Forms, so Plato's equally intense understanding of the centrality of rhetoric to dialectic and philosophy has been denied. Both denials deprive us of Plato's power and insight. These denials also deprive rhetoric and composition studies of power. The revolutionary aspect of Plato resides in his use of dialectic and rhetoric, his connection of form to human activity. Dialectic has particular importance for current rhetoric and composition pedagogy. At the center of dialectic lies activity between two fully participating sides. Dialectic denies passivity, the attribute that most characterizes education and that depends completely on a denial of individual power. In other words, passivity denies the dynamic capacity of students' ethos, traps them in triviality, and therefore stifles their power. From this point of view, and from Plato's point of view in Phaedrus, the teaching of philosophical rhetoric and dialectic is a subversive act, a call to mutual activity that obliterates the familiar passiveness.

Plato cannot divide the activity of dialectic from rhetoric, as Aristotle does in his simultaneous elevation and cordoning off of rhetoric in Book I of the Rhetoric (1932, p. 1). When Aristotle states that rhetoric is the counterpart (the antistrophos) of dialectic in the first sentence of the Rhetoric, he has separated the two activities. For Plato, rhetoric without dialectic diminishes it to the status of cookery and cosmetics. Philosophical rhetoric must partake of the mutuality of dialectic. Rhetoric can be profoundly good or profoundly bad for Plato, depending on its relationship to dialectic, its relationship to ultimate reality, and the striving for contact with it. There can be no 
philosophical rhetoric if whole pieces of discourse are not used. Nor can there be philosophical rhetoric if all five canons are not included. The famous passage in Phaedrus discussing discourse as an organic body provides one of Plato's strikingly graphic explanations for this attitude toward the potential power of language (Jowett, 1928, p. 309). If meaning is to emerge from the discourse, if language is given the opportunity to achieve its power, language must be used interactively and must aspire to contact beyond the apparent world.

Given the kind of connection and dialectical interaction Plato requires, the reader can see why sophistic rhetoric - the kind represented in different ways by Polus, Callicles, and Gorgias in Gorgiaswould not work for Plato. This kind of rhetoric did not engage whole human beings. Technical rhetoric, the kind propounded in the many handbooks then in circulation promising quick language fixes of power, engaged even less of the essential person than sophistic rhetoric. Plato overcomes these two kinds of rhetoric by repeatedly showing us philosophical rhetoric, the interaction of dialectic and rhetoric. The form of each dialogue acts as another utterance of this primary fact.

Two of the familiar forms of the contemporary use and reception of classical rhetoric rely on leaving Plato out of classical rhetoric or, worse, claiming he rejected rhetoric. This kind of historicizing leads to formulizing of the kind we see in the truncated canons of contemporary presentations of classical rhetoric: a categorical structure that contains only remnants of the original theory. If the new rhetorics are going to work, they will have to follow such writers as Kennedy, Ong, and Lunsford and Ede in fully reinscribing Plato's rhetoric.

\section{NOTES}

1. Edwin Black, in "Plato's View of Rhetoric" (1958/1979, p. 179), argues that more than one kind of rhetoric is treated in Gorgias. Black states, "It is impossible to maintain that Plato intended the Gorgias to be a total condemnation of all rhetoric as a 'knack' and a 'counterfeit of politics' when, in that very dialogue, he already sketches out some of the conditions of a rhetoric which would deserve the name of art."' I thank David Mair for long discussions of philosophical and technical rhetoric.

2. See Dodds (1959, pp. 229-230) and Kennedy (1980, p. 49).

3. See my article "A Manifesto: The Art of Rhetoric" (1986) for a fuller examination of this influential book. 
4. Classical technical rhetoric, as George Kennedy and others define it, differs from the contemporary field of technical writing. Contemporary technical writing is a form of reference discourse and deals with strategies for conveying specialized information.

5. See Keith V. Erickson (1976) for an analysis of Aristotle's development as a rhetorical theorist. Erickson shows how Aristotle also modified his attitudes toward rhetoric.

6. In "A Small History of Rhetoric," in Walter Benjamin (1981), Eagleton presents one of the most persuasive interpretations of classical rhetoric that I have seen. By explaining to his readers the cultural, linguistic, personal, and political power that inheres in classical rhetoric, Eagleton shows that classical rhetoric is the only set of language theories that takes account of nearly all human interactions. It is significant to note that Eagleton begins his history of classical rhetoric long before the appearance of Aristotle or even Plato: He begins with the language world of Corax and Tisias. I thank David Gross for introducing me to this Eagleton piece and for long discussions of rhetoric, theory, and power. The Research Council of the University of Oklahoma provided a grant for researching this article; a College of Arts and Sciences grant provided the time for writing.

7. For an important analysis of some of these writing issues, "Plato's Pharmacy," in Derrida (1981).

\section{REFERENCES}

Anderson, J. R. (1980). Cognitive psychology and its implications. San Francisco: W. H. Freeman.

Aristotle. (1932). The rhetoric of Aristotle. (L. Cooper, Trans.). Indianapolis: Bobbs-Merrill.

Black, E. (1985). Plato's view of rhetoric. In K. V. Erickson (Ed.), Plato: True and sophistic rhetoric (pp. 171-191). Amsterdam: Rodopi. (Reprinted from Quarterly Journal of Speech, 1958 44, 361-374.)

Cicero. (1970). Brutus. In J. S. Watson (Ed. and Trans.), Cicero on oratory and orators. Carbondale: Southern Illinois University Press.

Connors, R. J., Ede, L. S., \& Lunsford, A. A. (Eds.). (1984). Essays on classical rhetoric and modern discourse. Carbondale: Southern Illinois University Press.

Corbett, E. P. J. (1971). Classical rhetoric for the modern student (2nd ed.). New York: Oxford University Press.

Derrida J. (1981). Dissemination. (B. Johnson, Trans.). Chicago: University of Chicago Press.

Dodds, E. R. (ed.) (1959). Plato: $A$ revised text with introduction and commentary. Oxford: Clarendon.

Eagleton, T. (1981). Walter Benjamin: Or towards a revolutionary criticism. London: Verso.

Eagleton, T. (1983). Literary theory: An introduction. Minneapolis: University of Minnesota Press.

Ehninger, D. (1968). On systems of rhetoric. In D. Ehninger (Ed.), Contemporary rhetoric (pp. 49-58). Glenview, IL: Scott Foresman. (Reprinted from Philosophy and Rhetoric, 1968, 1, 131-144.) 
Enos, R. L. (1975). Cicero's forensic oratory: The manifestation of power in the Roman republic. Southern Speech Communication Journal, 40, 377-394.

Enos, R. L. (1979). The advocates of pre-Ciceronian Rome: Cicero's standard for forensic oratory. Communication Quarterly, 13, 54-62.

Erickson, K. V. (1976). The lost rhetorics of Aristotle. Communication Monographs, 43, 229-237.

Erickson, K. V. (Ed.). (1976). Plato: True and sophistic rhetoric. Amsterdam: Rodopi.

Febvre, L., \& Martin, H. J. (1984). The coming of the book. (D. Gerard, Trans.). London: Verso.

Freedman, A., \& Pringle, I. (Eds.). (1980). Reinventing the rhetorical tradition. Conway, AR: L\&S Books.

Grimaldi, W. M. A., S.J. (1972). Studies in the philosophy of Aristotle's rhetoric. Wiesbaden: Frans Steiner Verlag.

Grimaldi, W. M. A., S.J. (1980). Aristotle, rhetoric I: A commentary. New York: Fordham University Press.

Hackforth, R. (1952). Plato's Phaedrus. Cambridge: Cambridge University Press.

Havelock, E. A. (1963). Preface to Plato. Cambridge, MA: Harvard University Press.

Havelock, E. A. (1978). The alphabetization of Homer. In E. A. Havelock \& J. B. Hershbell (Eds.), Communication arts in the ancient world. New York: Hastings House.

Hayes, J. R. (1978). Cognitive psychology: Thinking and creating. Homewood, IL: Dorsey Press.

Jowett, B. (Trans.). (1928). The works of Plato (I. Edman, Ed.). New York: Modern Library.

Kaufer, D. S. (1978). The influence of Plato's developing psychology on his views of rhetoric. Quarterly Journal of Speech, 64, 63-78.

Kennedy, G. (1963). The art of persuasion in Greece. Princeton: Princeton University Press.

Kennedy G. (1980). Classical rhetoric and its Christian and secular tradition from ancient to modern times. Chapel Hill: University of North Carolina Press.

Knoblauch, C. H., \& Brannon, L. (1984). Rhetorical traditions and the teaching of writing. Upper Montclair, NJ: Boynton/Cook.

Lunsford, A. A., \& Ede, L. S. (1984). On distinctions between classical and modern rhetoric. In R. J. Connors, L. S. Ede, \& A. A. Lunsford (Eds.), Essays on classical rhetoric and modern discourse. Carbondale: Southern Illinois University Press.

Mackin, J. H. (1969). Classical rhetoric for modern discourse. New York: Free Press.

Mahoney, P. (1969). Marshall McLuhan in the light of classical rhetoric. College Composition and Communication, 20, 12-17.

McKeon, R. (Ed.). (1947). Introduction to Aristotle. New York: Random House.

McLuhan, M. (1962). The Gutenberg galaxy. Toronto: University of Toronto Press.

Montale, E. (1982). The second life of art. (J. Galassi, Trans. and Ed.). New York: Ecco.

Nadeau, R. (1969). Delivery in ancient times: Homer to Quintilian. Quarterly Journal of Speech, 50, 53-60.

Ohmann, R. (1976). English in America. New York: Oxford University Press.

Ong, W. J., S.J. (1958). Ramus, method and the decay of dialogue: From the art of discourse to the art of reason. Cambridge, MA: Harvard University Press.

Ong, W. J., S.J. (1981a). McLuhan as teacher: The future is a thing of the past. Journal of Communication, 31, 129-135.

Ong W. J., S.J. (1981b). The presence of the word: Some prolegomena for cultural and religious history (2nd ed.). Minneapolis: University of Minnesota Press. 
Ong, W. J., S.J. (1982). Orality and literacy. London: Methuen.

Pater, W. (1910). Plato and Platonism. London: Macmillan.

Plato. (1952). Gorgias. (W. C. Helmbold, Trans.). Indianapolis: Bobbs-Merrill.

Plato. (1956). Phaedrus. (W. C. Helmbold \& W. G. Ranbinowitz, Trans.). Indianapolis: Bobbs-Merrill.

Plato. (1959). Gorgias. (E. R. Dodds, Trans.). Oxford: Clarendon Press.

Rose, M. (1981). Sophisticated, ineffective books-the dismantling of process in composition texts. College Composition and Communication, 32, 65-73.

Scaglione, A. (1972). The classical theory of composition from its origins to the present: A historical survey. Chapel Hill: University of North Carolina Press.

Steiner, G. (1975). After Babel. New York: Oxford University Press.

Welch, K. E. (1986). A manifesto: The art of rhetoric. Rhetoric Society Quarterly, 16, 167-179.

Yates, F. A. (1966). The art of memory. Chicago: University of Chicago Press.

Kathleen E. Welch writes on the contemporary reception of classical rhetoric as well as on contemporary rhetoric and composition issues. Her work has appeared in Rhetoric Society Quarterly, Oldspeak/Newspeak: Rhetoric Transformations, edited by Charles Kneupper, and Biography. She is Assistant Professor of English at the University of Oklahoma, where she teaches writing and rhetorical theory. She has also written on classical rhetoric issues as they apply to nonfictional prose, especially autobiography. 